DOI https://doi.org/10.18551/rjoas.2017-12.46

\title{
POTENTIAL ENTOMOPATHOGENIC FUNGI TO CONTROL SCALE INSECT PEST ON CITRUS TANGERINE (CITRUS SUHUIENSIS TAN.)
}

\author{
Triwiratno A.*, Wuryantini S., Agustina D. \\ Indonesian Citrus and Subtropical Fruits Research Institute (ICSFRI), Batu, Indonesia \\ *E-mail: anangtriwiratno@gmail.com
}

\begin{abstract}
Achiving of food self-sufficiency can be done by using of local potential that is by agribusiness in Indonesia. One potential locally owned citrus agribusiness was the use of entomopathogenic fungi to improve the productivity of citrus. Reports showed decrease in productivity due to infestation of scale insect. The experiment was conducted at the Integrated Laboratory of Indonesian Citrus and Subtropical Fruit Research Institute in October 2013 to October 2014. The study began with a survey for scale insect infestation on citrus crops in high land, medium land and low in dry and rainy seasons. Taken from a collection of entomopathogenic fungi associated with scale insect in the field. Collection of fungi isolated from single conidia and its ability to infect selected scale insect. Entomopathogenic fungi were further tested for the viability and pathogenicity against scale insect. The results showed that the sclae insects attacked citrus were types of L.beckii and A.Aurantii. The highest attack occurred at low land during the dry season by L.beckii with population of 4.2 heads increased to 5.5 individuals per $10 \mathrm{~cm}$ in the rainy season. Viability test results showed that the isolates had viability above $50 \%$ were SKB4K, SKD1K and SBB3K for 73.6, 61.6 and $53 \%$ respectively, which were collected during the dry season. While isolates obtained in the rainy season were SBWD2H and SBWD3BH, each with aviability of 77.3 and $78.3 \%$ respectively. Pathogenicity test results showed that there were 6 isolates known to have potential as entomopathogenic fungi for controlling scale insect, namely, SBWB2H, SBWD2H, SBWD3BH, SKD1K, SBWD1K and SBB3K which had pathogenicity over $50 \%$ up to 14 days.
\end{abstract}

\section{KEY WORDS}

Citrus, scale insect, enthomopathogen fungi, viability, pathogenicity.

Problem encountered in developing citrus as one of national fruits is the low fruit quality. The low productivity is partly due to the existence of pest infestation of scale insect. Scale insect is now a major pest of citrus, whose population is very high, and causes damage to the production of citrus fruits (Meekes, 2001, Meekes et al., 2002; Triwiratno, 2004; Triwiratno and Yunimar, 2005). Scale insect with high population density attacking citrus plants causesleaves and fruits fall before ripening, as well as twigs and stems of plants die (Triwiratno et al, 2003a).

Brown scale insect ( $L$. beckii) have natural enemies from fungi member of family Aschersonia (Meekes, 2001; Meekes et al., 2002; Triwiratno, 2004; Triwiratno and Yunimar, 2005; Liu et al., 2005; Jun-Zhi et al., 2005; Dolinski and Lacey, 2007). The fungi can control brown scale insect because they produce secondary metabolites which is insecticidal, namely destruxins A4 and A5 which is a compound of depsipeptida (Krasnoff and Gibson, 1996) and Ascherxanthone A (Isaka et al, 2005).

Citrus crops in Indonesia are planted and cultivated commercially in lowland $(0-400 \mathrm{~m}$ above sea level (asl), medium land $(400-800 \mathrm{~m}$ above sea level), and highland $(>800 \mathrm{~m}$ asl). Commercial citrus varieties most widely grown in Indonesia areof tangerine (C. suhuiensis Tan.) with a population of $75 \%$, mandarin (C. reticulata) with a population of $10 \%$, and pummelo (C. grandis) with a population of $6 \%$ of all citrus population grown in Indonesia (Balitjestro, 2010). 
This study aims to (1) determine the type and population of scale insect that attack citrus plants on three types of elevation during dry season and rainy season. (2) Selection, viability testing, and pathogenicity of fungal isolates against scale insect.

\section{MATERIALS AND METHOD of research}

Research conducted at the Integrated Laboratory of Indonesian Citrus and Subtropical FruitsResearch Institute (ICSFRI), Tlekung, Batu. The research was conducted in the dry season and rainy between October 2013 and October 2014. Location forobservation of scale insect population and sampling of fungi associated with scale insectat highland was Bangli Regency, Bali;at medium land was Banyuwangi Regency, East Java; and at lowlandwasSambas Regency, West Kalimantan.

Isolation of fungi associated with scale insect andpropagate single conidia. Technique for isolationof fungiassociated with infestation of scale insect was performed per method of Liu et al. (2005 and 2006) and del Prado et al. (2008). Samples of scales section infested with the fungus was sampled using a needle loop and inoculated into petri dishes containing PDA (Potato Dextrose Agar) medium comprising of $50 \mathrm{mg} / \mathrm{L}$ teramisin. Fungal cultures incubated at a temperature of $25-30^{\circ} \mathrm{C}$ for approximately 7-14 days until fungal colonies filled the cup. Each colony of fungi that grow was subsequently rejuvenated into a PDA medium and incubated to produce conidia period.

Rearing scale insect. Propagation (rearing) of scale insect used Banjar tangerine as host plant, planted in polybags diameter of $30 \mathrm{~cm}$. 20-30 heads of first instar larvae (crawlers) of brown scale insect still actively moving (aged 1 day) were taken from a citrus plant having severe infestation of brown scale insects and inoculated onto each green leaf. The edges of leaves inoculated with crawler were limited by using wet tissue paper folds to prevent the leaving of the larvae of the leaf. The larvae of brown scale insectwere reared in a screen house at a temperature of about $25^{\circ} \mathrm{C}$ until imago reached 30 days and ready for treatment.

Selection of entomopathogenic fungi. Selection of entomopathogenic fungiwas done against isolates that have the phenotype of entomopathogenic and have the ability of Lethal Concentration 50 (LC 50) within 14 days. Pure fungi were isolated on PDA then incubated at $25-30^{\circ} \mathrm{C}$ for \pm 30 days or until colonies filled the petri dish. The numberof conidia was calculated by Haemocytometer to achieve the density of 107 conidia / ml. Suspension was aseptically put into handsprayer using a micropipette. The percentage of mortality was calculated by formula (Wahyono and Tarin, 2007).

Viability of entomopathogenic fungi conidia. Results obtained from the selection that had the ability above LC 50 at 14 days, meaningthat they were pathogenic against scale insect, continued counting the viability of the fungi. Fungal colonies fromselection results were grown on PDA to fulfill the cup. Conidia were harvested by adding $10 \mathrm{ml}$ of sterile distilled water containing $0.02 \%$ Tween 80 into the cup to form a suspension containing cultured conidia masses. The number of conidia on mass suspension was counted with Haemocytometer until reachingdensity of 102 conidia / $\mathrm{ml}$ by serial dilution then $0.1 \mathrm{ml}$ was taken using a micropipette and spread onto PDA medium surface in petri dishes by using spread plate method and flattened with dryglassky (Alves et al., 1998 cit. Francisco, 2006). Conidia in PDA medium incubated at room temperature for 24 hours to form conidia germination (Skrobek, 2001).

Fungus pathogenicity testagainst scale insect. Pathogenicity test wasmerely done to isolate of selection results. The experimental design used in the study was Random Block Design factorial with three variables. The first variable was fungal isolates; the second variable was density of application conidia;and the third variable was days of observation. Replications were three times. Total conidia calculated by Haemocytometer. Dilution was to obtain conidia density of 102-107 conidia / ml. Suspension was aseptically put intohandsprayer using a micropipette. The percentage mortality was calculated by formula (Wahyono and Tarin, 2007). 


\section{RESULTS AND DISCUSSION}

Survey result of scale insect population on tangerine. Scale insect that attacked citrus plants was a type of $L$. beckii and $A$. Aurantii. The highest attack occurred on the stems of citrus grown in the lowlands with the scale insect population of L. beckii was 4.2 heads per $10 \mathrm{~cm}$ rod (Figure 2). High scale insect populations in the lowlandssupposedly linked to conditions of high humidity on the tangerine plant, where the sample collected in the district of Sambas, West Kalimantan generally known of having rainfall throughout the year for 12 months.

L. beckii liked the dense tree canopy, and severe attacks usually occur in the central part of the tree canopy (Futch et al., 2001; Knapp, 2003; Triwiratno, 2004; Anonymous, 2007). The attacks on the stems, leaves and fruits found on the plant in the field caused typical symptoms of damage on the surface and the appearance of dotted and dull.

Imago $L$. beckii is dark brown with varied shapes that was long, circular and coma. Scale insect generally has a size of 1.0 to $3.0 \mathrm{~mm}$ and has a sort of shield on his back. Scale insect reproduce sexually or parthenogenesis. Most female scale insects can produce 40-80 eggsand placed in groups around the body that will hatch on the eighth day after the egg is produced. In the dry season, the eggs hatch in 15-20 days, while in the rainy season, hatching time is longer (Fasulo and Brooks, 2004). Crawler of scale insectwas white and runs very slowly, usually found on the stems and leaves sidelines. Crawler can survive for three days without food nutrients and can move only a few hours, then settled on a part to develop into adults (Grafton et al., 2000).

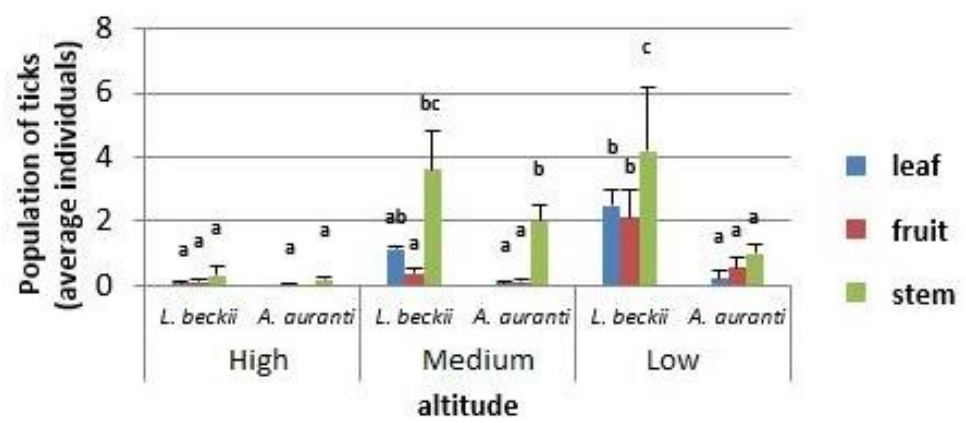

Figure 1 - Population and species of scale insects that attacked tangerine (C. suhuiensis Tan.) at highland, medium land and low land in dry season

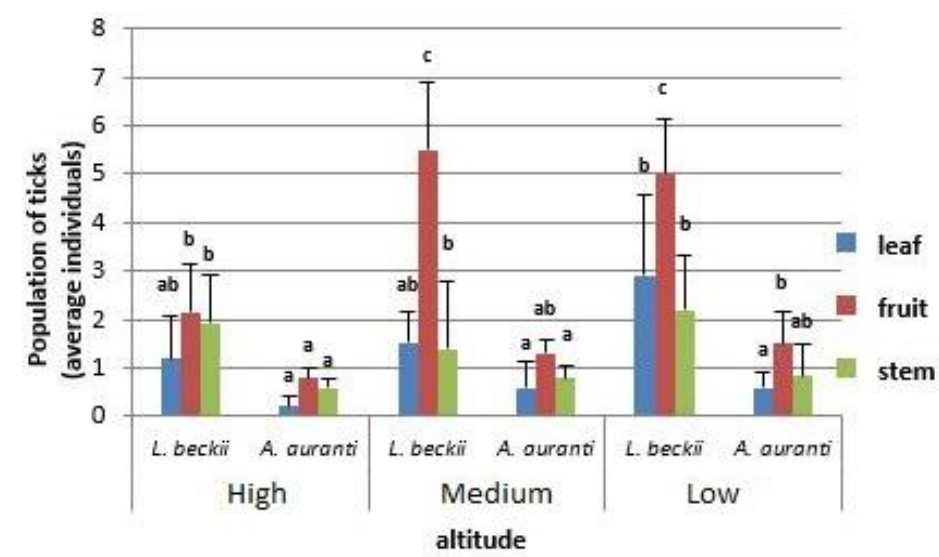

Figure 2 - Population and species of scale insects that attackedtangerine (C. suhuiensis Tan.) at high land, medium land and low land in rainy season.

Female insect changed skin twice, while the male had four skin changes before they reached the adult stage with wings. In a year, usually there are three or more generations. Scale insect can survive on host plants by sucking fluids from the leaves, fruit, branches, and 
stems of its host plant, causing chlorosis, leaf drop, incompleted ripening, abscission of fruits, dried branches and plant death (Fasulo \& Brooks, 2004).

Observations of the attacks carried out in rainy season was in conjunction with the fruit began to grow. The existence of new growing fruitsstimulated transfer of the crawler to move to get a young plant parts that will be used as a place to live when he became imago. The highest scale insectpopulation was $L$. beckii at the lowlands and the medium that was between 5 to 5.5 heads per fruit (Figure 2). While the population on the stems and leaves was lower.

A. Aurantii female mite had a hard body covering, round-shape and was maroon. While the body coveringof the male larvae was oval and smaller. Body shield of the of the female adult had a diameter between 1.5-2 $\mathrm{mm}$. The larvae were brown with a very small body size (Amitaningsih, 2005). According Efendi (2009) Adult female was oval, had diameter of 2 to $2.3 \mathrm{~mm}$, was spherical orange or dark brown, and produce 60-150 crawlers (first instar larvae were active).

Selection of entomopathogenic fungi from host plant type oftangerine (Citrus suhuiensis Tan.) in dry season and rainy season. Isolated fungi from three altitudes resulted 12 fungus isolates suspected entomopathogenic against brown scale insect, i.eSB B1 K, SB B2 K, SB B3 K, SB D1 K, SB D2 K (from Bali), SBW D1 K, SBW D2 K, SBW D3 K, SBW B1 $\mathrm{K}$ (from Banyuwangi), KSB4, KS D1 K, KS D2 K (from West Kalimantan). Fungus samples inoculated on PDA mostly obtained from the leaves and stems infected by brown scale insects. According Wraight et al, (2007) entomopathogenic fungi are adapted to dry conditions with sufficient moisture to actively infect pests (for example, on the abaksial surface of leaf or in the foldof insect cuticle membranes). Generally, entomopathogenic fungus infection against brown scales marked by orange or yellow fungal hyphae attached around the body of the insect.

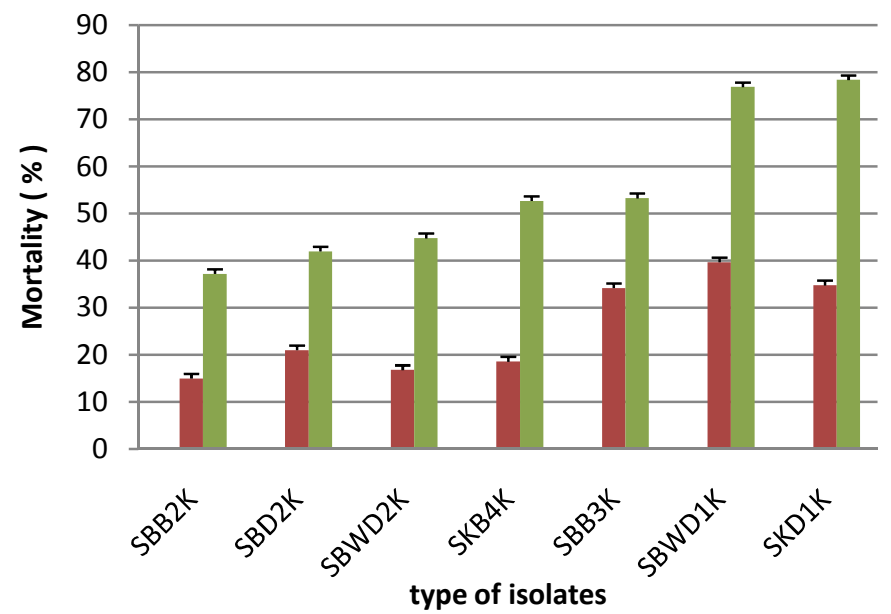

- Hari Ke- HO

- Hari Ke- H7

- Hari Ke- H14

Figure 3 - Mortality of $L$. beckii by seven isolates of entomopathogenic fungiisolated from scale insect on tangerine host plant in dry season

Mortality data from the selection trials resulted four species isolates that have the highest pathogenicity, namely, SK D1 K (Sambas), SBW D1 K (Banyuwangi), SB B3 K (Bali) and SK B4 K (Sambas) with a mortality rate of L, beckii was $78.4 \%, 76.9 \%, 53.3 \%$ and $52.7 \%$ respectively in 14 days. Other isolates werevonly able to control $L$, beckii less than $50 \%$ for 14 days (Figure 3). Isolates obtained from the same host insect but of different topographic had different virulence (Fatiha et al, 2007). This was shown from L. beckii mortality data produced by seven different isolates. SK D1 $\mathrm{K}$ isolates originating from the lowlands had the highest degree of pathogenicity compared to other isolates. This was because the population of host plant in the lowland was better. In addition, the environmental conditions at the low landcould create the characters of the physiology of fungi that were more virulent than the others originating from the highlands and medium. 
Isolated fungi from three altitudes resultednine isolates of the fungus suspected entomopathogenic against brown scale insect, i.e. SB B1 H, SB B2 H, SB D2 H, SB D3 H (from Bali), SBW D2 H, SBW B2 H, SBW H D3B, D3C SBW H (from Banyuwangi), and SK $\mathrm{B} 1 \mathrm{H}$ (from West Kalimantan) (Figure 4).

Alavo et al, (2004) asserts that the host range and ecological conditions can influence the genetic diversity that directly affect the virulence of a fungus power. Zhen et al, (2005) states that the virulence of entomopathogenic fungi is influenced by the character of physiology. Meanwhile, physiology character of entomopathogenic fungus closely related to the rate of growth, sporulation, conidia germination and tolerance to temperature differences.

According Prayogo (2006) the concentration of fungi with conidia density of 107 conidia $/ \mathrm{ml}$ is the standard concentration in testing biological products. Prayogo \& Marwoto (2005) also declare that the minimum dose of conidia fungal pathogens that can lead to death of insects is 103 conidia / $\mathrm{ml}$. Previous research has shown that B. bassiana entomopathogenic fungi on the density of 107 conidia / ml could infect termites up to 100\% (Desyanti et al., 2005).

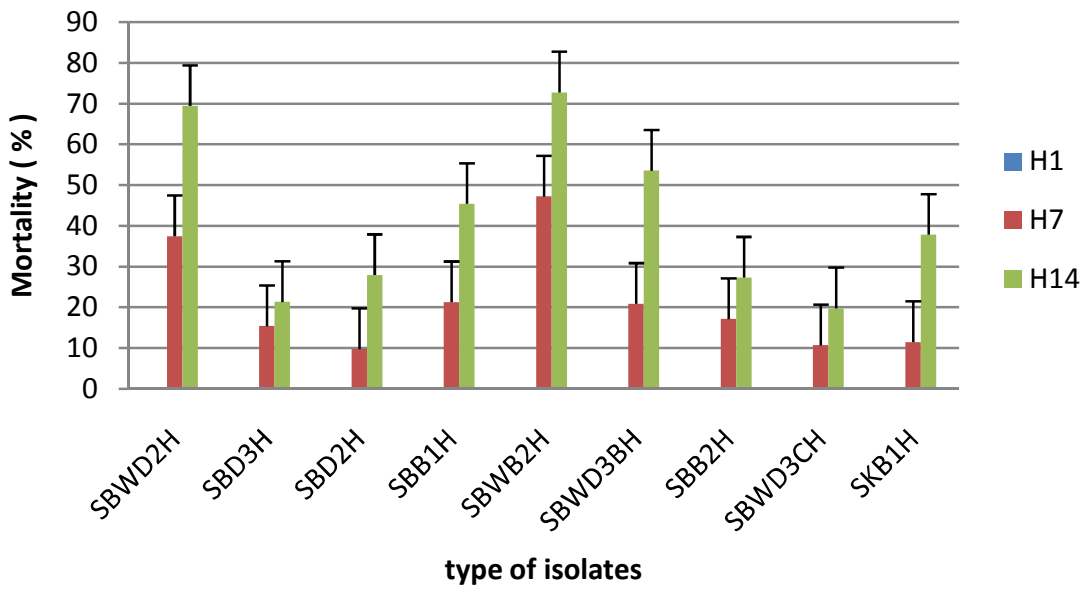

Figure 4 - Mortality of $L$. beckii by nine isolates of entomopathogenic fungi isolated from scale insect on tangerine host plant in rainy season

Viability of selection result of entomopathogenic fungiin dry season and rainy season. A total of seven isolates of the selection result, namely, SB B2 K, SB B3 K, BSD2, SBW D1 K, SBW D2 K, SK B4 K and SK D1 K (Figure 5) were tested for conidia viability to identify the speed of conidia germinated within 24 hours. The ability of fungi conidia to germinate within a certain time could be seen from the level of its viability. The higher the percentage of viability, the shorter the germination time required.

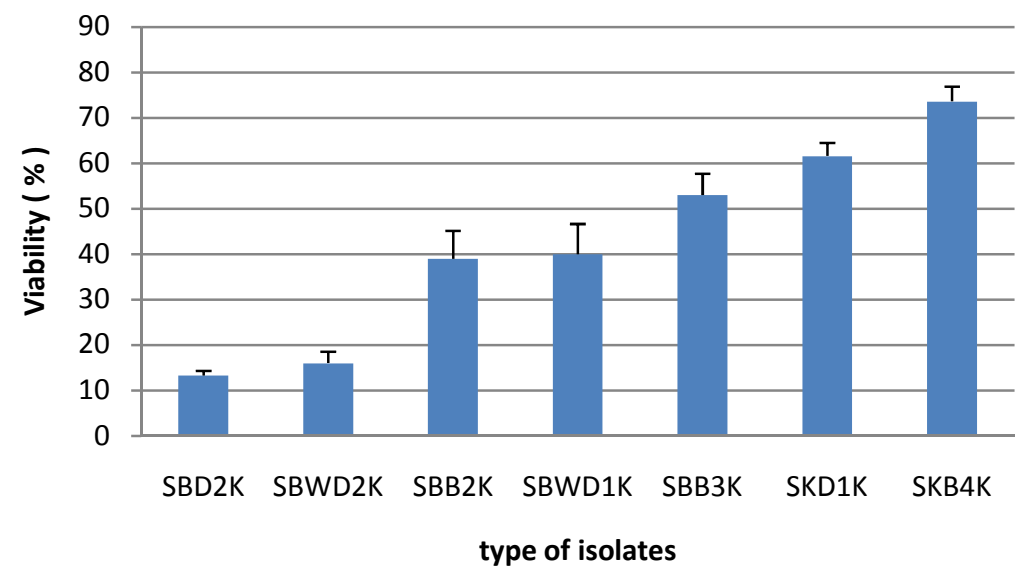

Figure 5 - Viability ofconidia of seven entomopathogenic fungi isolated from scale insect on tangerine host plant in dry season 
Different isolates types had a significant influence on the value of the viability of conidia of the fungal isolates $(P<0.05)$. Of the seven tested isolates, there were three types of isolates that hadthe highest level of viability of fungal isolates conidia, namely,SK B4 K, SK $\mathrm{D} 1 \mathrm{~K}$ and SB B3 $\mathrm{K}$ of $73.6 \%, 61.6 \%$ and $53 \%$ respectively, while four other isolates had a percentage viability of less than $50 \%$ (Figure 5 ). Viability of isolates conidia ofSB B3 K was relatively lower than isolates SK D1 K, even though the two isolates were statistically not significantly different $(P>0.05)$. Based on the results of previous studies, the percentage of fungal conidia viability could reach $90 \%-100 \%$ (Rahayu, 2009). The highest viability was achieved by SBW D2 $\mathrm{H}$ and SBW D3B H with viability of $77.3 \%$ and $78.3 \%$ respectively (Figure 6). In this viability test, fungal isolates were incubated at room temperature of $25^{\circ} \mathrm{C}$. The optimum temperature for growth, pathogenicity and survival of entomopathogenic fungus was around $20-30^{\circ} \mathrm{C}$ (Morissey \& Osbourn, 1999).

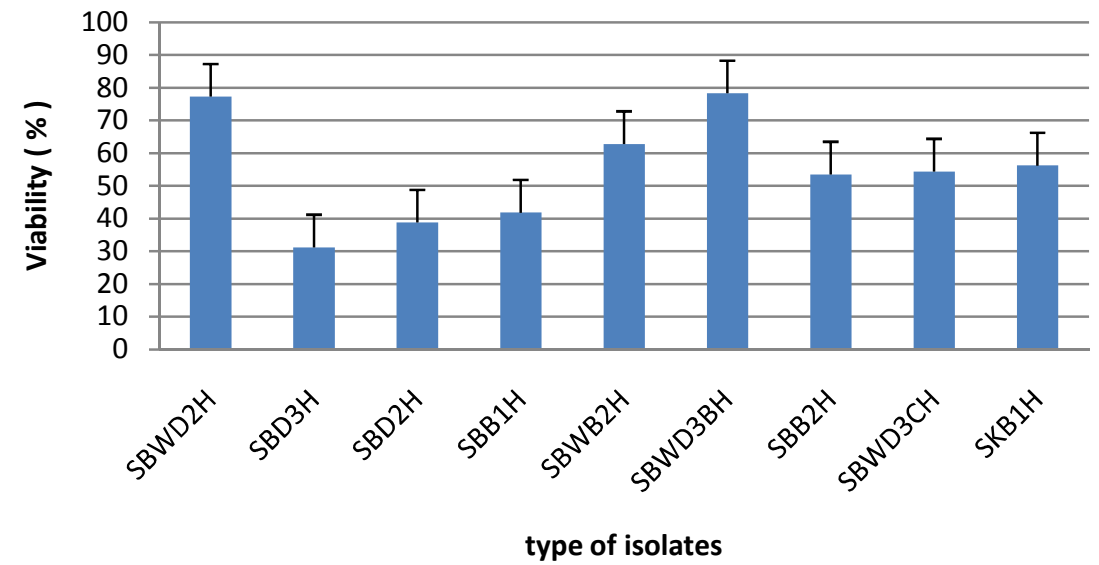

Figure 6 - Viability of conidia ofnine entomopathogenic fungi isolated from scale insect on tangerine host plant in rainy season

Viability of entomopathogenic fungus spore was influenced by temperature, humidity, $\mathrm{pH}$, solar radiation and chemicals, such as nutrients and pesticides (Muller Kongler, 1967 in the Robert \& Yendol, 1971; Riyanto, 1993). In this viability test, fungal isolates were incubated at room temperature of $25^{\circ} \mathrm{C}$. The optimum temperature for growth, pathogenicity and survival of entomopathogenic fungus was around $20-30^{\circ} \mathrm{C}$ (Morissey \& Osbourn, 1999).

Pathogenicity of entomopathogenic fungi from tangerine host plants. A total of six isolates were tested for pathogenicity to determine the level of virulence. All three isolates were selected based on the selection test with mortality, and the highest conidial viability were SBW D1 K, SK D1 K, SB B3 K, SBW D2 H, SBW B2 H, and SBW D3 BH with mortality of $L$. beckii was $81.1 \%, 73.6 \%, 68.8 \%, 69 \%, 72 \%$, and $54 \%$ respectively, for 14 days at a concentration of 107 conidia / ml. Observation of the first day of treatment showed that all concentration treatment of each type of isolates had not shown $L$. beckii death.

The increase of $L$. beckii deaths can be observed on the seventh day and 14th day after the application. Increased mortality rates can be compared with the control treatment. In this case, the control treatment merely contained tween 80 . Of all the control treatment, the mortality rate of each isolate was $0 \%$. Differences in density offungus conidia had a significant influence on mortality of $L$. beckii of each isolatestype $(P<0.05)$.

Isolates of SB B3 K generated from the highlands of Kintamani-Bali had conidial viability rate of $53 \%$ on PDA. Although the percentage of the conidia viability was medium, this isolates at selection test could control L. beckii up to $53.3 \%$ at a concentration of 107 conidia / $\mathrm{ml}$ for 14 days. Based on this result, the SB B3 $\mathrm{K}$ isolates was further tested to determine the pathogenicity against $L$. beckii.

Significant difference between conidia density and observation time indicated an interaction between them $(P<0.05)$. Differences in conidia density gave effect to the increase in the value of the percentage of brown scaleinsect mortality. Isolates of SB B3 K could 
control L. beckii at the highest concentrations of $10^{4}, 10^{7}$ and $10^{3}$ conidia / $\mathrm{ml}$ for $70.8 \%$, $68.8 \%$ and $59.9 \%$ respectively at day $14^{\text {th }}$. Isolates of SB B3 K at the concentration of $10^{4}$ conidia / $\mathrm{ml}$ could control $L$. beckii higher than that at the concentration of $10^{7}$ conidia / $\mathrm{ml}$, as well as that at the concentrations of $10^{5}$ and $10^{6}$ conidia / $\mathrm{ml}$ could control $L$. beckii lower than that at the concentrations of $10^{4}$ and $10^{3}$ conidia / $\mathrm{ml}$ (Figure 7).

This study indicated that a high conidia density did not always give a high mortality rate. This condition is contrary to previous statement that the higher conidia given, the higher mortality generated. This was caused by the host population density and environmental conditions. LC50 value generated from this isolates SB B3 K was $4,5 \times 10^{7}$ conidia / $\mathrm{ml}$ on day $14^{\text {th }}$.

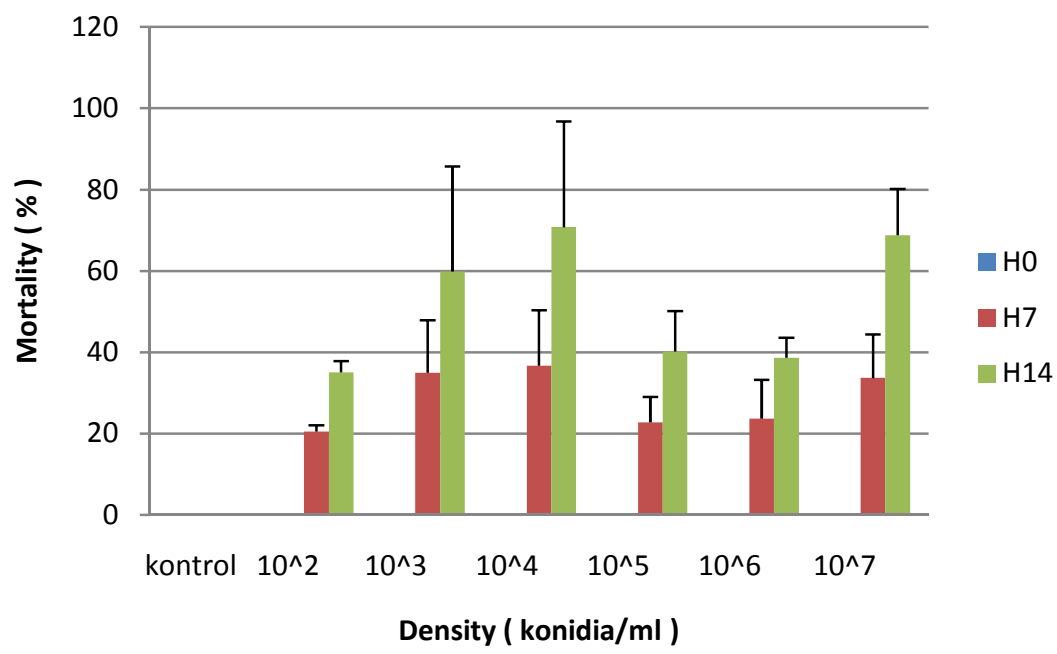

Figure 7 - Mortality of $L$. beckii by isolates of SB B3 Kwith density of $10^{2}-10^{7} / \mathrm{ml}$ at $1^{\text {st }}$ day, $7^{\text {th }}$ day and $14^{\text {th }}$ day

Isolates of SBW D1 $\mathrm{K}$ came from the medium land in Banyuwangi had a viability level of $40 \%$ which were grown on PDA. Although the percentage of viability was relatively very low $(<50 \%)$, this isolates, at the selection phase, could control $L$. beckii up to $76.9 \%$ at a concentration of $10^{7}$ conidia / $\mathrm{ml}$ for 14 days. Isolates of SBW D1 K was suspected can germinate well when having directcontact with the host than on PDA medium containing high carbohydrates. According to Nelson et al, (1983), high carbohydrate content causes a loss of viability of entomopathogenic fungi. Based on this, the isolatesof SBW K D1 wasfurther tested to determine the ability of pathogenicity against $L$. beckii.

Isolatesof SBW D1 K could control $L$. beckii mostly at the concentrations of $10^{7}, 10^{6}$ and $10^{5}$ conidia / $\mathrm{ml}$ for $46.2 \%, 42.4 \%$ and $35.4 \%$ respectivelyon the seventh day. Mortality valueon the seventh day was different from the fourteenth day. The longer the time the application made, the higher the value of $L$. beckii mortality resulted from each concentration. On day fourteenth, mortality at concentrations of $10^{7}, 10^{6}$ and $10^{5}$ conidia / ml increased by $81.13 \%, 63.5 \%$ and $51.2 \%$ respectively, whereas at lower concentrations, that were, $10^{4}, 10^{3}$ and $10^{2}$ conidia / $\mathrm{ml}$ could control $L$. beckii less than $50 \%$, i.e. $48.1 \%, 38.7 \%$ and $25 \%$ on the fourteenth day. The LC50 value generated from isolates of SBW D1 K was 3,3x106 conidia / $\mathrm{ml}$.

Isolates of SK D1 K came from the lowland in Sambas, West Kalimantan. These isolates had conidial viability value of $61.6 \%$ on PDA medium. The resultsof selection test indicated that the mortality rate of $L$. beckii reached $78.4 \%$ at day $14^{\text {th }}$. The ability of these isolates to infect $L$. beckii was high as well as its viability rate, therefore, it was necessary to test the isolate pathogenicity.

On the seventh day, the isolates of SKD1 K could controlL. beckii at concentration of $10^{5}, 10^{6}$ and $10^{7}$ conidia / $\mathrm{ml}$ for $25.8 \%, 23.5 \%$, and $20.4 \%$ respectively. The value of mortality increasedup to the fourteenth day. On day $14^{\text {th }}$, the mortality of $L$. beckii at concentration of $10^{7}$ and $10^{6}$ conidia / $\mathrm{ml}$ increased more rapidly than that at the concentration of $10^{5}$ conidia / 
$\mathrm{ml}$ for $73.6 \%, 69,9 \%$ and $56 \%$ respectively. Whereas the isolate at concentration below $10^{4}$, $10^{3}$ and $10^{2}$ conidia / $\mathrm{ml}$ could control L. beckii less than $50 \%$, i.e. $45.4 \%$, $32.4 \%$, and $28 \%$ respectively at day $14^{\text {th }}$. The LC50 value generated from isolates of SK D1 K was $3,3 \times 105$ conidia / $\mathrm{ml}$.

Isolatesof SBW D2 $\mathrm{H}$ collected from host plants at the medium land in Banyuwangi, East Java were isolated from leaves during the rainy season. Based on the LC50, isolates of SBW D2 Hwere the most virulent to $L$. beckii since the conidia of $10^{3}$ conidia / ml on day $14^{\text {th }}$ could infect $50 \%$ of the scale insect. The LC50 value from isolatesof SBW D2 H was 7,2×106 conidia / $\mathrm{ml}$.

Isolatesof SBW B2 H collected from host plants at the medium land in Banyuwangi, East Java were isolated from leaves during the rainy season. Based on the LC50,isolates of SBW D2 H were the most virulent to $L$. beckii since the conidia of $10^{3}$ conidia / ml on day $14^{\text {th }}$ could infect $50 \%$ of the scale insect. The LC50 value from isolates of SBW B2 H was $1,04 \times 106$ conidia / $\mathrm{ml}$.

Isolatesof SBW D3 BH collected from host plants at the medium land in Banyuwangi, East Java were isolated from leaves during the rainy season. Based on LC50, isolates of SBW D3 $\mathrm{BH}$ hada lowervirulence than isolates of SBW B2 $\mathrm{H}$, because the conidia of $10^{5}$ conidia / $\mathrm{ml}$ on day $7^{\text {th }}$ couldinfect only $50 \%$ of the scale insects, whereas isolates of SBW B2 $\mathrm{H}$ could get LC50 at conidiaof $10^{4}$ conidia / $\mathrm{ml}$. The LC50 value from isolatesof SBW D3 BH was $5.3 \times 104$ conidia / ml.

\section{CONCLUSION}

Scale insectsthat attacked tangerine (C. Suhuiensis Tan.) at the highlands, medium lands, and low lands during the dry season and the rainy season weretypes of $L$. beckii and $A$. Aurantii. The highestpopulation occurred at the low lands during the dry season by $L$. beckii with a population of 4.2 heads and increased to 5.5 heads per $10 \mathrm{~cm}$ in the rainy season. Selection result, viability test and pathogenicity showed that there were six fungal isolates that have potential as entomopathogenic fungi to control scale insects, namely, SBW B2 $\mathrm{H}$, SBW D2 H, SBW D3 BH, SK D1 K, SBW D1 K and SB B3 K.

\section{REFERENCES}

1. Alavo T.B.C. 2004. Virulence of strains of the enthomopathogenic fungus Verticillium lecanii to Aphids: Strain improvement. Journal. Arch of Phyt. and Plant Protection. 34(6): 379-398.

2. Amitaningsih, D. 2005. Inventarisasi Kutu Sisik pada Tanaman Jeruk di Loka Penelitian Tanaman Jeruk Dan Hortikultura Subtropik Tlekung-Batu. Laporan PKL. Malang. Jurusan Biologi Fakultas MIPA UM.

3. Anonim. 2007. Lepidosaphesbeckii (Newman, 1869). http://www.itis.gov/ servlet/SingleRpt/RefRpt?

4. Prado, E. N. 2008. Effect of Two Entomopatogenic Fungi in Controlling Aleurodicus cocois (CURTIS 1846) (Hemiptera: Aleyrodidae). Chilean. J. Agric. Res. 68(1): 21-30.

5. Desyanti Y.S. 2007. Keefektifan Beberapa Spesies Cendawan Entomopatogen untuk Mengendalikan Rayap Tanah Coptotermes gestroi WASMANN (Isoptera: Rhinotermitidae) dengan Metode Kontak dan Umpan. Jurnal. IImu \& Tekonolgi Kayu Tropis. 5(2): 22-25.

6. Dolinksi, C. and L. A. Lacey. 2007. Microbial Control of Arthropods Pests of Tropical Tree Fruits. Neotrop. Entomol. 36(2): 161-179.

7. Efendi, M. 2009. Distribusi Hama Kutu Sisik Merah (Aonidiella aurantii) Pada Perkebunan Jeruk Manis (Citrus sinensis) dan Jeruk Keprok (Citrus reticulata). Skripsi Tidak Diterbitkan. Malang: Jurusan Biologi Fakultas Saintek UIN.

8. Fasulo, T. R. dan R. F. Brooks. 2004. Scale Pests of Florida Citrus. http://edis.ifas.ufl.edu /pdffiles/CH/CH05900.pdf.

9. Francisco, E. A., D. A. Mochi, A. do C. B. Correia \& A. C. Monteiro. 2006. Influence of Culture Media in Viability Test of Conidia of Entomopathogenic Fungi. Ciencia Rural. 36: hal $1309-1312$. 
10. Futch, S. H., C. W. McCoy, and C. C. Childers. 2001. A Guide to Scale Insect Identification. EDIS, University of Florida.

11. Grafton, E. E. Cardwell. 2000. Pest Notes: Cottony Cushion Scale. http://www.ipm.ucdavis.edu. Diakses 29 Mei 2012.

12. Knapp, J. L. 2003. Control of Insects, Mites and Diseases of Florida's Dooryard Citrus Trees. http://www.floridaplantS.com.

13. Isaka, M., S. Palasarn, K. Kocharin, and J. Saenboonrueng. 2005. "A Cytotoxic Xanthone Dimer from the Entomopathogenic Fungus Aschersonia sp. BCC 8401" Jurnal of Natural Production 68(6): 945 - 946.

14. Jun-Zhi, Q. et al. 2005. "RAPD and large subunit nuclear rDNA sequence analyses of the entomogenous fungus Aschersonia”. Ch. J. of Agricultural Biotechnology 2005 (2): 85-90.

15. Krasnoff, S. B. and D. M. Gibson. 1996. "New Destruxins from the Entomopathogenic Fungus Aschersonia sp." Jurnal of Natural Production 59 (5): 485 - 489.

16. Liu, M. 2005. "What's in a Name? Aschersonia insperata: a new Pleonamorphic Fungus with Characteristics of Aschersonia and Hiirsutella". Mycologia 97(1):246-253.

17. Liu, M., P. Chaverri and K. T. Hodge. 2006. "A Taxonomic Revision of the Insect Biocontrol Fungus Aschersonia aleyroidis, its Allies with Stromata and their Hypocrella Sexual States". Mycologycal research 110(5): $537-554$.

18. Meekes, E. T. M. 2001. "Biological Control of Whiteflies with Entomopathogenic Fungi Tritrophic Interactions between Aschersonia spp. - Bemisia argentifolii and Trialeurides vaporarium - and Glasshouse Crops", Dissertation. Wagebingen University.

19. Meekes, E. T. M., J. J. Fransen and J. C. van Lenteren. 2002. "Pathogenicity of Aschersonia spp. Against Whiteflies Bemisia argentifolii and Trialeurides vaporarium". Jurnal of Invertebrate Pathology 81(1): 1-11.

20. Morissey, J.P. 1999. Fungal Resistance to Plant Antibiotics as a Mechanism of Pathogenesis. American: Microbiology and Molecular Biology. 78(2): hal 17-34.

21. Nelson, P.E., T.A. Toussoun \& W.F.O. Marasas. 1983. Fusarium spesies. An Illustrated Manual For Identification, The Pennsylvania State University Press, London.

22. Prayogo, Y. \& Marwoto. 2005. Kerentanan Jamur Entomopatogen Verticillium lecanii terhadap beberapa jenis fungisida. Agrivita. 27(1): 51-59.

23. Prayogo, Y. 2006. Upaya Mempertahankan Keefektifan Kapang Entomopatogen Untuk Mengendalikan Hama Tanaman Pangan. J. Litbang Pertanian. 25(2): hal 1-7.

24. Rahayu, L.O. 2009. Isolasi, identifikasi filogenetik dan uji patogenisitas konidia kapang entomopatogen terhadap kutu sisik coklat (Lepidoshapes beckii Newman) hama tanaman jeruk.Tesis. Program Pasca Sarjana Universitas Brawijaya Malang. 110 hal.

25. Riyanto. 1993. Prospek Penggunaan Beuveria bassiana Untuk Penegendalian Hama Tanaman Perkebunan. Prosiding Makalah Simposium Patologi Serangga I. PEI dan Fakultas Pertanian UGM. Yogyakarta.

26. Robert, D.W \& G.W. Yendol. 1971. Use of Fungi for Microbial Control of Insect. Microbial Control of Insect and Mites. 125 - 145.

27. Skrobek, A. 2001. Investigation on The Effect of Entomopathogenic Fungi on Whiteflies. Dissertation. Der Hohen Landwirtschaftlichen Fakultat der Rheinischen Friedrich. Wilhelms. Universitat Zu Bonn.

28. Triwiratno, A.; S. Wuryantini, dan Yunimar. 2003a. Identifikasi Penyebab Penyakit Jamur Merah di Pertanaman Jeruk Kabupaten Karo Propinsi Sumatera Utara, Sirkular Inovasi Teknologi Jeruk Vol. 11, November 2003.

29. 2004. "Teknologi Pengendalian Kutu Sisik/Kutu Perisai (Lepidoshapes beckii Newman, Unapsis citri) pada Tanaman Jeruk". Balai Penelitian Tanaman Jeruk dan dan Buah Subtropika, Batu.

30. Yunimar. 2005. "Pengembangan Pemanfaatan Jamur Merah Aschersonia sp. Sebagai Entomopatogen Kutu Sisik pada Tanaman Jeruk". Balai Penelitian Tanaman Jeruk, Batu.

31. Wahyono T.E. 2007. Uji Patogenisitas Agen Hayati Bauveria bassiana dan Metarhizium anisopliae terhadap Ulat Serendang. Bul. Teknik Pertanian. 12(1): hal 4-7.

32. Zhen, H. L., L. Andre \& H. C. Huang. 2005. Isolation and characterization of chitinases form Verticillium lecanii. Journal Microbiology. 51(12): 145-155. 